\title{
A crítica junguiana: Estudos Culturais e além*
}

\author{
Claudia Canuto**
}

\section{Da Literatura Comparada aos Estudos Culturais}

Em meio ao contínuo debate sobre o significado da cultura e da sua relação com os estudos literários propriamente ditos, e sobre qual departamento, disciplina e/ou linha de pesquisa acadêmica está melhor qualificada para coordenar esta junção, cabe-nos ponderar, como junguianos e comparatistas, o papel da crítica junguiana neste contexto. Nào dizemos, propositalmente, “o papel da crítica literária junguiana" mas, simplesmente, "o papel da crítica junguiana"- o que, para bom entendedor, significa que olhamos com certa simpatia para o relatório Bernheimer (1993), o qual recomendou aos comparatistas tópicos multiculturais, multidisciplinares e multitextuais:

Thus conceived, comparative literature has some affinities with work being done in the field of cultural studies. But we should be wary of identiffing ourselves with that field, where most scholarship has tended to be monolingual and focused on issues of popular cultures.'

No entanto, como bem ressaltou Marjorie Perloff ${ }^{2}$ entre outros, enfatizar o domínio da língua estrangeira e da "alta cultura" como marcas diferenciadoras entre as habilidades do comparatista e aquelas do crítico cultural é, na melhor das hipóteses,

Tradução do original em inglês. (C) Cláudia Canuto, 1999

"É Ph.D. em Literatura Comparada pela Vanderbilt University (1989) e obteve o DOTE da Universidade de Cambridge (1991). Ensina na Pós-Graduação em Letras da UFAL, onde fundou (1995) o AION - Grupo junguiano de Estudos e algumas vertentes da crítica cultural.

1. "Assim concebida, a literatura comparada tem algumas afinidades com o que está sendo feito no campo dos estudos culturais. Mas deveríamos ter cuidado em não nos identificar com estes, onde a maior parte das pesquisas tende a ser monoglota e se concentrar em questões de cultura popular." Bernheimer, "The Bernheimer Report" in Bernheimer, 45.

2. Marjorie Perloff, "Literature' in the Expanded Field." Bernheimer, 178. 
contraditório, pois as mudanças propostas por Bernheimer diziam querer acabar, oficialmente, com o velho eurocentrismo comparatista e com as antigas noçòes de "centro e periferia." Dizemos oficialmente porque a literatura comparada já há bastante tempo lida também com a cultura popular e com a multidisciplinaridade, além de incorporar uma certa variedade de mídia, como o filme. O comparatista de há muito está à vontade para estudar tanto a "alta cultura" quanto a "cultura popular," e para usar o conhecimento e a metodologia de disciplinas afins - a psicologia entre elas - na crítica literária. Já em 1954 Harry Levin falava da conexão entre a literatura comparada e as outras disciplinas, incluindo a antropologia e a psicologia, e cerca de dez anos depois chamava a atenção para a relevância, no âmbito da literatura comparada, "de outras disciplinas, além da literatura: notavelmente a lingüística, o folclore, as artes plásticas, a música, a história, a filosofia, e, possivelmente, a psicologia, a sociologia e a antropologia." 3 Portanto a visão que atribuiria aos estudos culturais o monopólio da cultura popular, e à literatura comparada "a visão de elite," não pode ser tão facilmente endossada. Roland Greene sugere, ao contrário, que o campo e o objeto de estudos do comparatista são tão diversos e tão amplos que fazem com que a disciplina se caracterize exatamente por ser multifacetada:

...comparative literature is necessarily the most unsettled, the most difficult, the most mercurial of all theliterary fields, because unlike the national ones it is undergoing reinvention at least every generation or so, perhaps every few years, and in principle every time a scholar begins to negotiate a new project out of this rich array of models. Moreover, comparatists who are pressing against different boundaries will often seem to bave little in common with each other: a literary historiographer of the Middle Ages as against a scholar of contemporary cultural studies, a philologist of Arabic and Spanish versus a literary theorist who works with French and German. In principle this problem of identity within the discipline becomes a greater challenge with every generation, as the pertinent

3. Levin, 9. 
borders of the field are redefined and enlarged and the practitioners - if they really are practitioners of comparative literature - find themselves further from one another than ever. ${ }^{4}$

O motivo de enfatizarmos aqui esta característica da literatura comparada é menos para destacá-la por razòes de política acadêmica do que para ressaltarmos o fato de que os estudos culturais se aproximaram bastante desta disciplina - e para lembrarmos ainda que, apesar disso e talvez inexplicavelmente, a crítica junguiana de há muito se encontra em casa na literatura comparada mas ainda está à espera de ser acolhida com mais calor pelos estudos culturais. É bem verdade que a literatura comparada, por ter tanto o indivíduo quanto o grupo como objeto de estudo, continua tendo um espectro mais amplo do que os estudos culturais, sendo-lhe portanto naturalmente mais fácil lidar com um número maior e mais variado de abordagens. Mas é nosso objetivo aqui tentar mostrar que a crítica junguiana se entrosa tão bem nos estudos culturais como na literatura comparada - e que o motivo de isto ainda nào ter acontecido em larga escala parece se dever mais a atitudes inconscientes ou apressadas tanto dos críticos culturais quanto dos junguianos do que a qualquer inadequaçào intrínseca à abordagem.

Talvez a primeira hesitaçào dos estudos culturais em utilizarem a psicologia como aparato crítico esteja no sentimento quase instintivo, mas obviamente errôneo, de que a psicologia se ocupa principalmente com o indivíduo. Da mesma forma que a literatura comparada, no entanto, vemos que a psicologia estuda tanto o indivíduo como o grupo. O próprio Freud analisou a origem psicológica e o papel das culturas e da civilizaçào, e Jung, embora nào tenha se preocupado em estabelecer uma "teoria da cultura" propriamente dita, deixou dados suficientes para que seus seguidores construíssem nào apenas uma interpretação da cultura, mas várias. Entre

4. "...a literatura comparada é, por necessidade, a menos sossegada, a mais dificil, a mais mercurial de todas as áreas literárias, porque, ao contrário das literaturas nacionais, ela é reinventada ao menos a cada geração (ou quase isso) - talvez a cada poucos anos, e em princípio toda vez que um estudioso começa a escolher um novo projeto entre a sua rica coleção de modelos. Além do mais, os comparatistas que exploram limites diferenciados [na disciplina] freqüentemente parecem ter pouco em comum uns com os outros: a um historiógrafo literário que lida com a Idade Média se opõe um estudioso dos estudos culturais contemporâneos, a um filólogo do árabe e do espanhol se opõe um teórico da literatura que trabalha com o francês e o alemão. Por princípio este problema de identidade dentro da disciplina se torna um desafio cada vez maior a cada geração, à medida que os limites pertinentes à área são redefinidos e ampliados, e que os praticantes - se eles forem realmente praticantes da literatura comparada-se encontram mais longe uns dos outros do que nunca." Roland Greene, "Their Generation" in Bernheimer, 144-5. 
os grandes teóricos da psicologia, apenas Lacan parece ter atualmente entrada franca entre a maioria dos estudiosos da crítica cultural, devido sem dúvida mais à sua aproximaçào metodológica com a lingüística do que por sua participaçào com a psicologia propriamente dita.

Se isto for correto, cabe-nos perguntar: neste aparente descaso dos estudos culturais para com a psicologia junguiana, encontraremos talvez um preconceito acadêmico? Ou estaremos apenas constatando um certo "cochilo" dos críticos da cultura, devido à usual lentidão com que as diversas áreas de estudo se agrupam e se transformam, lentidão esta compreensivel mas nem sempre justificável em termos da estabilidade dos departamentos e das idéias acadêmicas?

É verdade que a maior parte dos críticos da cultura, tanto aqui quanto no exterior, é composta de vários segmentos daqueles que há nào muito tempo se dedicavam à crítica social, e que se sentiram apátridas com a destruiçào do bloco socialista. Este grupo, sempre na vanguarda e na esquerda política e acadêmica, constitui um dos mais criativos e inovadores blocos ideológicos da academia, e não nos cabe aqui condená-los, mesmo porque devemos muito, em termos de apoio e de formação, ao espírito liberal — palavra usada aqui no sentido norte-americano, ou seja, significando exatamente o oposto do que veio a significar entre nós — com que em geral acolhiam idéias díspares e às vezes até por demais ousadas para o mundo acadêmico de entào, predominantemente conservador. 5 No entanto, queremos lembrar que este grupo sempre esteve bastante mais à vontade com as abordagens de origem marxista, as quais não só estabeleceram uma longa tradiçào e uma multiplicidade de escolas intelectualmente notáveis, mas que também se inseriam num contexto mais amplo, buscando uma rápida mudança política e social. Foi este, parece, o grupo de acadêmicos que deu impulso aos estudos culturais e ao "multiculturalismo" (embora este último, ao menos temporalmente, apareça conectado ao fenômeno da "globalização" e, portanto, ao do "novo capitalismo" - vínculo este que por vezes desliza, numa quase imperceptível porém má ginástica mental, para o campo ideológico). Assim, os estudos culturais tem uma aliança natural com as teorias que outrora serviam de apoio aos críticos materialistas herança, talvez, de um passado em que as teorias psicológicas (principalmente as junguianas) não lhes pareciam tào interessantes, já que estas em geral nào se adequavam, sem certos malabarismos, à etiologia e à política das "lutas de classe."

5. Em especial, sou grata à fina inteligência e à paciência de Hans-Joachim Schulz, ao brilhantismo de Donald Ault, e ao talento do poeta e critico Stephen Spender, com quem tive o privilégio de estudar. 
Os estudos culturais parecem portanto ter-se firmado principalmente como uma saudável reação ao niilismo resultante da acreditada derrota das várias teorias que se embasavam nas esquerdas e que foram desaguar na perplexidade do "pósmoderno" e das "antiteorias." Nesta profunda tentativa de reestruturaçào que ainda confunde os meios acadêmicos (e que reflete neste nível a desestruturaçào do modelo social vigente na guerra fria), a crítica literária junguiana ainda permanece à parte nào só porque os junguianos dificilmente se sentem esvaziados e niilistas, como também porque não contam nem com a vantagem do que era familiar e confortável às esquerdas, nem com o que lhes era familiar e por vezes desconfortável, como alguns dos formalismos (pensamos naqueles de direita, em grande parte originados do New Criticism).

A pergunta que portanto se coloca neste momento é a seguinte: nào fará a crítica literária junguiana também parte legítima da crítica cultural, ao menos nos freqüentes casos em que se ocupa da psicologia coletiva, da mesma forma como inegavelmente pertence ao âmbito tanto das críticas psicológicas como da literatura comparada?

\section{Cultura e multiculturalismo}

Quem define a cultura? Embora não seja a nossa intenção aqui sumarizar uma história das teorias da cultura, vemos que a preocupaçào em se apropriar dela e defini-la é antiga também nos estudos literários. Barbara M. Benedict mostra que já no século dezoito inglês as antologias literárias eram compiladas visando cumprir a promessa de que a cultura podia ser absorvida através dos valores literários, os quais passaram a exercer assim uma funçào reguladora desta. De fato, em 1869, o poeta e crítico literário vitoriano Matthew Arnold afirmou que a cultura era "o contato com o que de melhor se pensou e se disse no mundo." Esta declaraçào veio a influenciar bastante na elaboraçào dos cânones literários e nutriu a idéia de "alta cultura" que durante tanto tempo dominou o mundo acadêmico; idéia que os críticos de esquerda, como Adorno e Horkheimer, denunciaram em 1944 como "a indústria capitalista da cultura." "Sabemos todos que foram os críticos marxistas os que primeiro cogitaram da desconstruçào das teorias da cultura, exibindo assim o aparato ideológico-político sobre os quais elas se estruturam.

6. Adorno e Horkheimer, passim. 
Portanto, quando falamos da crítica junguiana como crítica cultural, estamos abrindo um espaço para que ela seja analisada também do ponto de vista ideológico, como qualquer outra teoria. Aliás uma das primeiras recomendações em programas de estudos culturais nos Estados Unidos atualmente é a de que o estudante se conscientize de que toda crítica cultural implica numa tomada de posição ética e política. Se adotamos a propagada visão de Hirsch em Cultural Literacy, bastante criticada por refletir apenas a cultura dominante no país ao elaborar o cânone ideal de um americano culto, ${ }^{7}$ certamente estaremos esposando valores bastante diferentes daqueles propostos por teóricos ou escritores que valorizam as produções culturais de minorias específicas ou os daqueles que abraçam o relativismo multiculturalista, ${ }^{8}$ o qual, em algumas elaborações teóricas, se estende também para um espaço multinacional.

Vemos portanto que a noção mais ou menos unificada de uma teoria da cultura de há muito se esfacelou, e que mesmo os conceitos hoje veiculados são parte de um debate e de uma negociaçào contínua entre um número crescente de teóricos provenientes de áreas e de ideologias bastante diversas. Do mesmo modo que as idéias de um Harold Bloom ou de um E.D. Hirsch podem ser criticadas sem que isto consiga invalidá-las de um ponto de vista absoluto, a crítica junguiana, ao participar de uma área em que é praxe a desconstrução das premissas ideológicas embutidas numa certa abordagem, está também exposta às interpretaçòes, errôneas ou nào, acerca de tais premissas. Isto talvez preocupe os junguianos, os quais em geral estào mais interessados em mergulhar em postulados psicológicos do que nas supostas ideologias que lhes possam ser atribuídas - preocupação talvez até mais compreensível e justificável neste caso devido à renitente campanha armada contra Jung, na qual se tenta desacreditá-lo com acusações que vão desde a haver sido ele mais um "místico" do que um psicólogo e cientista, até mesmo a de ter ele engrossado a fileira dos que apoiaram a inteligência nazista." Mas não se pode fugir de acusaçòes deste tipo, e devemos manter em mente que uma divulgação ainda mais extensiva de tais alegações aumentaria também a extensão de um nosso esclarecimento, além de nos auxiliar efetivamente não só em classificar à que

7. Lembramos que, no mesmo contexto, ao livro de Hirsch seguiu-se o de Harold Bloom, o qual propunha um cânone de um multiculturalismo global.

8. Shweder, passim.

9. Ambas as acusações são falsas. A segunda pode ser desmentida por qualquer um que conheça a vida e a obra de Jung, e no Brasil foi desmentida publicamente em periódicos nacionais por vários profissionais respeitáveis, entre os quais a admirável Nise da Silveira. Quanto à primeira afirmativa também não é dificil de desprovar, baseando-nos na obra junguiana. 
ideologia(s) a crítica junguiana realmente pertence, como também em mapear as diversas sub-correntes ideológicas dentro desta nossa linha crítica.

\section{A crítica junguiana como crítica da cultura}

Se bem que a mais óbvia e característica área de atuação da crítica junguiana em geral se situe no campo da representação, lidaremos aqui com conceitos que também nos parecem particularmente importantes para a construção de uma teoria junguiana da cultura, e que dizem respeito à reprodução cultural. A maior parte dos críticos da cultura, ao trabalharem com paradigmas construídos a partir de teorias econômicas e antropológicas e seus derivativos, parece definir a cultura como, essencialmente, algo que se aprende - e, conversamente, como algo que se ensina. Para eles, duas das principais maneiras como a cultura se reproduz são a "enculturaçào" ("enculturation") e a "difusão." Harris diz que "a enculturação é o ensino... através do qual a geraçào mais velha convida, induz e urge a geração mais jovem a adotar formas tradicionais de pensamento e comportamento '1". Já a difusào ocorre quando modelos de comportamento ou de significado culturais são passados de uma sociedade a outra. Vemos assim que a cultura pode ser reproduzida de dois modos: internamente, através da enculturaçào; e externamente, através da difusão. A enculturaçào reproduz a cultura de uma geração a outra, tanto quanto possível; e a difusão transporta uma cultura a outra. No presente, com o crescimento da tecnologia e a aproximaçào entre as culturas, o papel da difusão parece ter aumentado numa velocidade geométrica, resultando no fenômeno da multicultura (ou daquilo que, em outro contexto temporal, Marshall McLuhan chamara de "aldeia global").

Em tudo isto, vemos que uma parcela "inexplicável" dos costumes nào se transmite sempre homogeneamente através da enculturaçào. Mesmo numa cultura fechada, sem contato com povos diferentes que possam afetar a transmissào dos costumes (tal como o Butào permaneceu até há pouco), há sempre um momento em que uma nova descoberta, ou um novo pensamento em um ou mais dentre os indivíduos membros desta cultura pode acabar por transformá-la internamente. Foi provavelmente assim que, quando um anônimo troglodita inventou a roda, ele acabou por modificar não só a sua cultura como aquelas dos tempos futuros, sem sequer ter a possibilidade de avaliar o impacto de sua descoberta. Neste ponto a

10. Harris, 7. 
pergunta que se nos impòe é: o que causaria esta mudança na relativa estabilidade de uma cultura fechada? e de onde surge a inovação num caso onde nào encontramos difusào?

É aqui que a teoria junguiana da cultura nos surge não com uma resposta pronta e acabada, mas com um campo aberto para pesquisas e estudos. Ao formular os arquétipos como "feixes de energia," Jung estabeleceu uma conexão psico-bioneurológica entre a mente e a cultura. Em que medida os arquétipos seriam responsáveis pelas sinapses por vezes imprevisíveis e inexplicáveis que causam os nossos novos pensamentos e descobertas? Se bem que Jung pensasse que os arquétipos (como os instintos) eram nódulos herdados de energia residentes no inconsciente coletivo, manifestando-se ("irrompendo" ou "constelando") através de imagens às quais chamou de imagens arquetípicas, as razões pelas quais algumas destas imagens (e não outras) irrompem em determinada cultura num tempo determinado ainda são motivo de debate:

O objetivo muis abrangente da critica arquetípica éo de compreender como os arquétipos operam culturalmente, e para isto uma preocupação central do crítico arquetípico é com a forma pela qual certos periodos da bistória ou climas culturais são propicios - ou parecem ser - à manifestação de modelos e simbolos arquetipicos recorrentes... ${ }^{11}$

O próprio Jung sugere para isto uma resposta que se basearia numa interaçào entre o indivíduo e a cultura, através do inconsciente coletivo. Podemos assim talvez preencher a lacuna deixada por outros tipos de crítica cultural ao adotarmos a crítica junguiana. À pergunta de por que uma cultura fechada e que não seja afetada pela difusào não permanece imutável em sua enculturação, poderíamos responder com a teoria junguiana da irrupção dos arquétipos. Ao nível arquetípico, os seres humanos estão todos conectados pelo inconsciente coletivo. Assim, diríamos que a difusào pode ocorrer também ao nível inconsciente. Como críticos junguianos da cultura é-nos lícito considerar que uma cultura pode se propagar apenas de forma visivel e externa, ou, adicionalmente, de forma subreptícia e interna. Assim se explicariam, interessantemente, as similaridades de representaçào em culturas que provavelmente nào tiveram contato umas com as outras - as pirâmides com degraus dos astecas e as pirâmides com degraus egípcias, por exemplo. ${ }^{12}$ Portanto, para o

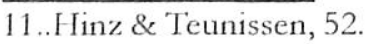

12. Há uma teoria biológica que postula que todo desenvolvimento alcançado por um membro de um segmento de uma espécie específica é acessível também aos membros longínquos desta mesma espécie. Possivelmente isto se dá também ao nivel cerebral/mental com suas conseqüências cognitivas e psicológicas. 
crítico junguiano da cultura a quebra na reproduçào enculturada de um grupo pode ser atribuída tanto a um fenômeno de difusào externa quanto a um outro a que chamaremos de difusão interna; e tal difusão interna pode ocorrer tanto ao nível espacial quanto ao nível temporal. Como observam Hinz e Teunissen,

... Os arquétipos estão sempre irrompendo na consciência a partir do nivel do inconsciente ou numinoso, mas diferentes arquétipos e complexos de arquétipos emergem em épocas diferentes. Assim as irrupsōes prometeicas pareceram inevitáveis no século deqenove; a Grande Mãe se faz visível em toda a parte no século vinte. A questão de se uma sociedade temporal particular é mais propicia do que outra em outra época e lugar ou a de se o arquétipo, tornando-se obssessivo, cria tal sociedade com todos os sets derivativos, é uma questão que o espaço e a própria naturęa das manifestacōes arquetípicas não nos permitirão responder aqui. ${ }^{13}$

Vemos, portanto, que a crítica junguiana realiza uma complementação das análises culturais mais divulgadas, enfatizando que nào é suficiente presumirmos que a causa das “quebras" (inovaçòes) na enculturação se dá invariavelmente devido à difusào como um fenômeno externo; para ela, é preciso que examinemos também as conexões com o que chamaremos de difusão interna, a qual explicaria os "deslocamentos" nas representaçòes de culturas diversas (como no caso dos astecas e dos egípcios) - bem como que compreendamos o fenômeno da irrupçào do arquétipo propriamente dito.

Num interessante artigo sobre a cultura e a anorexia nervosa, Suzanne Robell diz que "Jung parte da psicologia individual - sem nunca se esquecer de que o indivíduo pertence a uma espécie da qual herda suas características instintivas, tanto biológicas quanto psiquicas - para em seguida se deter nos aspectos da psicologia do coletivo." "Se bem que isto seja verdade, examinar a cultura a partir de uma progressào linear que vai do indivíduo para a cultura parece ter sido mais uma conveniência didática por parte de Jung do que uma causalidade real. Em toda a obra de Jung, o que aparece é uma constante interaçào, um fluxo, por assim dizer, entre os opostos - consciente e inconsciente - e neste caso a cultura se coloca no polo oposto ao do indivíduo. Diríamos portanto que o crítico junguiano da cultura nào deve se preocupar tanto em estabelecer progressòes lineares quanto em perceber esta constante interaçào, a qual pode, como a ouroboros, nào ter começo nem fim.

13. Hinz e Teunissen, 48.

14. Robell, 1. 
Jung acreditava que o mundo arquetípico sempre se manifestava em imagens de dupla polaridade, e que o contato direto com o arquétipo trazia mudanças para o consciente grupal. É que a energia arquetípica se concentra com tal intensidade em certos pontos determinados do inconsciente que estes irrompem para o consciente como a lava de um vulcào. Tais irrupções podem ser extremamente perturbadoras para o consciente grupal, fazendo com que a cultura se ressinta desta liberaçào; para Jung, este foi o caso da Alemanha nazista, cujo consciente cultural entrou em contato com o lado destruidor de um arquétipo marcial. ${ }^{15}$ Mas mesmo nos casos em que a irrupção de um arquétipo vem a resultar numa mudança cultural criativa e poderosa - como aconteceu em certas épocas e/ou regiões do mundo antigo, por exemplo — isto em geral se dá devido à uma certa interaçào com o indivíduo. Para Jung, há dois tipos nítidos e distintos de indivíduo: o cidadão comum e o cidadão excepcional — este, o "líder moral da humanidade." É a este último que cabe interagir com os arquétipos irrompidos, absorvendo-os e integrando-os ao consciente, para que assim se possa manter ou restaurar o equilíbrio ao nível do consciente cultural:

A integração de conteúdos inconscientes consiste num ato individual de realização, compreensão e valoração moral. Trata-se de uma tarefa extremamente dificicl que exige um alto grau de responsabilidade ética. Somente de poucos individuos pode-se esperar a capacidade para um tal desempenho, e esses não são absolutamente os líderes políticos mas os lideres morais da bumanidade. A preservação e o desenvolvimento da civilização dependem desses homens singulares... ${ }^{16}$

Vale ressaltar que embora Jung mencione aqui o "alto grau de responsabilidade ética" que caracteriza tal líder, esta qualidade não pode ser exigida do indivíduo normal como uma funçào a ser desempenhada; é, ao contrário, resultante da imensa força psíquica de que tal pessoa dispõe para absorver e integrar o arquétipo ao consciente, em vez de ser absorvida por ele. Toda vez que um arquétipo irrompe e não é integrado pelo consciente, o consciente é, no dizer de Jung, "possuído" pelo arquétipo - e este é uma força pura e bruta que, como os instintos, não entende a voz da ética nem da razão. É tal líder moral que "filtra"e serve de intermediário entre a descomunal força do arquétipo e o frágil consciente do ser humano comum. Jung chamou a este indivíduo, cujo consciente é extremamente forte, de "personalidade-maná." O filtro representado por tal indivíduo recebe a projeção dos níveis inconscientes do grupo, que só assim consegue manter o equilíbrio mental e

15. Jung, "A Luta com as Sombras," passim.

16. Jung, 42. 
restaurar a estabilidade cultural. Note-se que a este ponto a cultura terá sofrido transformações significativas devido ao que chamamos aqui de difusào interna.

Jung chama também a atençào para o fato de que o líder grupal nem sempre possui a necessária força e integração psíquicas para desempenhar esta função. Tratase aqui de um outro tipo de líder, do líder político - que, ao contrário do precedente, é na verdade o indivíduo mais fraco na cadeia cultural, sendo portanto aquele que mais rapidamente é arrastado e engolido pela força da irrupçào do arquétipo. Tal líder é freqüentemente aquele que posssui "a menor força de resistência, a menor consciência de responsabilidade e que, devido à sua inferioridade, demonstr[a] a mais forte vontade de poder." Ele liberta "tudo o que está em estado de irrupção" no inconsciente grupal e portanto o grupo o segue "com a força arcaica e incontrolável de uma avalanche" ${ }^{17}$ - freqüentemente para um destino destruidor. Este, diz Jung, foi o caso de Hitler e da Alemanha nazista, embora o estado psíquico que causou esta difusào cultural interna tenha afetado também a outros povos:

... Em cada um de meus pacientes alemães pude constatar um distúrbio do inconsciente coletivo. É possivel explicar essas derivacoues pela causalidade mas a explicação causal não satisfaz, pois compreendemos os arquétipos mais facilmente a partir de suas finalidades do que propriamente de suas causas. Os arquétipos que pude observar exprimiam primitividade, violência e crueldade....

...Essa conjuntura de fatos não era apenas uma manifestação teutônica, como se viu nos anos seguintes. O ataque tempestuoso de forras arvaicas foi quase universal. A principal diferença residia na própria mentalidade alemã que, em razão de sua extraordinária tendência para a massifícação, se mostrou mais propicia. ${ }^{18}$

Com esta declaraçào Jung torna claro que o movimento de massas é sempre um acontecimento perigoso, e que ele ocorre devido "à insurreiçào de forças adormecidas no inconsciente, dispostas a romper o conjunto de limites morais." Para que isto aconteça, freqüentemente é preciso que haja um estímulo ao nível consciente do grupo; um estímulo que desorganize a ordem tradicional e a cultura que a expressa - um estímulo, portanto, que pode operar ao nível da difusào cultural externa. No caso da Alemanha nazista, Jung aponta que "a derrota e a calamidade social" decorrentes da primeira grande guerra favoreceram o espírito

17. Jung, 41.

18. Jung, 40. 
gregário já bastante forte entre os alemàes, e com isto indiretamente ele sugere que a interaçào entre as culturas, baseada na difusão cultural, no colonialismo e na aculturação, é um fator que pode provocar - e frequentemente provoca - um desequilíbrio ao nivel do consciente grupal. É este desequilíbrio que instiga uma compensaçào arquetípica:

\section{...É evidente que para se produzir um movimento compensatório} desse tipo épreciso que algo esteja fora de ordem na atitude consciente; algo deve estar invertido ou fora de proporções, pois somente uma consciência desequilibrada pode provocar um movimento contrário no inconsciente. ${ }^{19}$

Para o crítico junguiano torna-se particularmente visível o estado de agitaçào arquetípica de uma cultura ao nível da representaçào. Os símbolos e signos que aparecem na literatura e em outros artefatos culturais servem como um aviso de perigo para aqueles que souberem lê-los, como sinais de uma catástrofe mental iminente, com a sua conseqüente desagregaçào cultural. Infelizmente, nem sempre os membros de um grupo possuem a chave exata para decifrar os códigos do inconsciente no momento adequado; mais - fazer parte de uma cultura prestes a ser inundada por conteúdos desorganizados inconscientes obscurece a capacidade individual crítica. Seria entretanto conveniente observarmos os artefatos culturais, bem como os sonhos recorrentes em uma cultura, para estarmos sempre alertas em caso de possíveis irrupçòes arquetípicas de efeito desagregador. Por isso é especialmente importante desencorajarmos qualquer tipo de censura. Jung diz que no momento em que os símbolos, os sonhos e as imagens arquetípicas "aparecem em um grande número de indivíduos [de uma cultura] e nào sào assimilados, eles começam a unir com força magnética os indivíduos isolados. Assim tem origem uma massa" 2n - da qual brevemente sairá um líder do tipo a que Jung chamou de "político," o qual tem muito pouca resistência à avalanche do inconsciente e é o primeiro a se deixar arrastar por ela. Devido ao fenômeno da massificaçào, ele puxará com ele o grupo.

Vemos assim que a crítica junguiana da cultura, longe de ser "vaga e csotérica," oferece chaves reais em níveis de análise politizada que uma crítica ao nível das interaçòes culturais externas por vezes nào alcança. Freqüentemente, a crítica junguiana da cultura é, nào antagônica, mas complementar a outras análises culturais. É interessante notarmos, adicionalmente, que as premissas junguianas sobre a cultura

19. Jung, 41.

20. Jung, 41. 
se baseiam em regras que Jung considerava bio-psíquicas. Portanto, o código de ética junguiano nào obedece a uma criaçào filosófica abstrata e idealista, mas as leis de um sistema que poderíamos classificar de "ecologia bio-psíquica." As culturas, como os seres humanos, vivem em um estado de equilíbrio dinâmico, por assim dizer, em que fatores novos causados por difusão externa e/ou interna perturbam a reprodução cultural homogênea e simples que ocorreria através da enculturação. À medida em que tais perturbaçōes conseguem ser absorvidas e integradas ao consciente cultural (às vezes tal integração é efetuada apenas ao nível de projeção sobre o líder moral), a cultura se enriquece e se mantém suficientemente estável. Quando, ao contrário, a força arquetípica nào encontra um "canalizador" (o qual freqüentemente é um indivíduo forte o bastante para integrar e absorver esta força sem se deixar destruir por ela), o grupo é arrastado e "possuído" pelo inconsciente, freqüentemente com efeitos devastadores para a cultura. A ética junguiana se baseia nessas premissas, concluindo que, no estágio de evolução atual, a grande maioria dos seres humanos não alcançou um estágio de individuação suficiente para resistir com autonomia à força da avalanche dos arquétipos irrompidos.

Jung não se ilude, portanto, com a capacidade ética do indivíduo comum a implicação é a de que mesmo um cidadão que sempre conseguiu agir de forma moral em períodos de estabilidade cultural pode se desestruturar completamente em períodos de forte irrupção arquetípica. O código de ética junguiano, se é que poderíamos chamá-lo assim, não prega conceitos, mas conscientizações; é só à medida que o ser humano conseguir aperfeiçoar o processo de individuação, tornando-se consciente das forças inconscientes de forma a poder controlá-las, que ele realmente terá a capacidade de agir de forma ética. De outra forma, continuará repetindo os mesmos erros, pois não terá eliminado a sua vulnerabilidade a um inconsciente que, ao se manifestar, o devora. É assim que ao apresentar uma Alemanha nazista arrastada por "uma maré de primitividade," Jung está não apenas condenando a ela, mas nos alertando de que o que aconteceu durante o hitlerismo nào é nem um fenômeno único na história nem está relegado a uma só cultura ou ao passado; é algo que pode eclodir em qualquer cultura desequilibrada por fatores de difusão interna e/ou externa:

O que deveriam ter feito os alemães? Todo alemão poderia ter reconhecido em HITLER as suas próprias sombras e percebido o terrivel perigo que representava. Cada um de nós poderia ter tomado consciência de sua própria sombra e ter-se encontrado com ela. Como então esperar que os alemães tivessem compreendido tudo isso se ninguém no mundo consegue compreender uma verdade tão simples? O mundo jamais aliançará um 
estado de ordem sem reconhecer essa verdade. Entretanto, perderiamos nosso tempo aduqindo todas as razões externas e secundárias possiveis para justificarporque esse estado não conseguiu ser alcançado, embora soubéssemos suficientemente que as condições para isso dependiam em larga escala de nossa capacidade de compreensão. ${ }^{21}$

Embora este ensaio, como dito de início, se atenha ao âmbito da reprodução cultural e não seja o nosso propósito neste momento examinar mais de perto as repercussões das afirmativas acima ao nível da representação, como críticos literários cabe-nos observar que, ao contrário da crítica cultural textual que examina os signos como elementos de convenção arbitrária ao nível consciente — posiçào esta originária de antropólogos que, como Geertz, definem a cultura como um sistema semiótico - o crítico junguiano deve se concentrar nos símbolos como elementos de uma multilinguagem inconsciente. É claro que parte deste trabalho consiste em conseguirmos realmente identificar o símbolo, sem confundi-lo com o signo. A própria psicologia junguiana tem sido criticada justamente porque Jung em alguns casos confundiu um com o outro, o que levou alguns críticos a pensarem que as imagens arquetípicas junguianas são na verdade signos culturais. Em nossa opinião, isto demonstra uma generalizaçào e uma compreensão por demais superficial dos conceitos junguianos, e de forma alguma desacredita as premissas básicas de Jung - mas demonstra a dificuldade que ainda temos em reconhecer a linguagem do inconsciente e em distinguir os seus símbolos.

Neste ponto é oportuno falarmos um pouco de certas declarações feitas mais ou menos recentemente por críticos junguianos que, como nós, desejam ver a crítica junguiana mais empregada nos estudos culturais. Partindo de um desejo de tornar a crítica junguiana "multicultural," Michael Vannoy Adams ${ }^{22}$ argumenta que é necessário redefinir o inconsciente coletivo para que este inclua não apenas fatores arquetípicos como também o que ele chama de "fatores estereotípicos" - entre os quais ele parece incluir os estereótipos raciais. Se bem que tenhamos enorme simpatia pelas noções reais de integração racial, parece-nos que uma "redefinição" do inconsciente coletivo ao nível preconizado por Adams é teoricamente irrealizável, por motivos evidentes, esperamos, à maior parte dos críticos junguianos; basta-nos dizer aqui que o arquétipo não é "transformável" por um mero desejo da vontade consciente, nào importa quão bem intencionado. O arquétipo é uma força

21. Jung, 44 .

22. Adams, passim. 
desconhecida e incontrolável que irrompe como lava e só pode ser trabalhado ao nível consciente, o que significa que é o consciente que muda, não a força inconsciente em si. O argumento de Adams equivaleria a dizer que vamos modificar o sentido de instinto, para nele incluirmos o equilíbrio racional. Obviamente estaríamos nos enganando com possíveis conseqüências perigosas - como, por exemplo, se ao julgarmos a razão tão instintiva quanto a libido freudiana pensássemos que esta última é tão acessível ao controle da mente consciente quanto aquela.

No entanto, o que a preocupaçào de Adams assinala é não só a necessidade já mencionada aqui de um maior conhecimento dos símbolos de forma a não os confundirmos com os signos culturais, como também a de esclarecermos uma questào que ainda parece confusa para os críticos junguianos: qual seja, a de se existe realmente um nível do inconsciente coletivo a que poderíamos chamar de "inconsciente cultural." Esta possibilidade se originou de declarações de Jung que diziam respeito nào só a possíveis diferenças no inconsciente coletivo de diversas raças humanas — à mente da raça negra, por exemplo, provavelmente "faltaria uma camada histórica inteira," enquanto que aquela de grupos étnicos distintos como, por exemplo, os alemàes, seria possivelmente afetada por irrupçòes arquetípicas temporalmente pertinentes ao seu grupo mas nào a outros. O que poderíamos concluir destas afirmativas? Em primeiro lugar, é preciso observarmos que certas idéias de Jung fazem parte de noçòes ainda nào contestadas em sua época. Jung partilhava não só da visão preconceituosa comum aos europeus de seu tempo que acreditavam que a "cultura" estava abaixo da "civilização" (Freud, por exemplo, fala das repressòes necessárias para mantermos um estado de civilização) e que as raças escuras, em geral, estavam num estágio mental menos evoluído do que as brancas - como também partilhava de um universo cultural ainda preso a Taine e à noção das "mentalidades." Inteirando-nos disto, é preciso analisarmos até que ponto estas idéias devem ser levadas a sério ao compilarmos as idéias que Jung sumarizou ao formular o conceito de inconsciente coletivo. Em nossa opinião, esta área ainda foi pouco debatida ou estudada; porém aceitarmos "níveis" no inconsciente coletivo nào precisa significar que abracemos também algumas concepçòes errôneas comuns aos europeus da época de Jung. Por exemplo, na medida em que os estudos etnográficos atuais parecem desacreditar a noçào de que as tribos negras africanas tivessem um cérebro inferior ao dos brancos europeus, aquilo que Jung apoiava entào por julgar fato comprovadamente científico perde a razào de ser com o resultado de que, fosse Jung vivo hoje em dia, provavelmente repudiaria tal noçào. Quanto à crença junguiana no conceito de "mentalidades," talvez nào possamos desacreditá-lo da mesma forma - pois o que é o próprio estudo junguiano 
das culturas senão um estudo das antigas "mentalidades" em roupagem nova? Portanto, nos indagarmos se existe realmente um nível no inconsciente que possa ser chamado, como o fez Joseph Henderson, de "inconsciente cultural," ${ }^{23}$ parece-nos uma pergunta legítima; o que não significa, necessariamente, que acreditemos na legitimidade do conceito enquanto resposta.

É necessário observarmos que a fraseologia de Henderson postula um inconsciente cultural, mas não um inconsciente coletivo cultural, como quereriam alguns outros, como Frantz Fanon ${ }^{2+}$ - posição esta que julgamos insustentável. No exame da proposta de Henderson, no entanto, devemos ponderar até que ponto tal distinção nos seria útil. Por exemplo, qual a vantagem em classificarmos certas imagens arquetípicas (tais quais os deuses germânicos, como Wotan) como estando alojadas num segmento cultural inconsciente? Será esta classificação realmente acertada, em termos de interações entre os arquétipos e a mente consciente grupal? Ou seria talvez mais apropriado reconhecermos tais imagens arquetípicas como partes da mente cultural consciente, já que toda imagem arquetípica representa uma projeção que já deixou o inconsciente coletivo? Haverá mesmo uma camada inconsciente e cultural mediando entre a força arquetípica do inconsciente coletivo e a mente consciente?

A crítica junguiana da cultura ainda está sendo construida à medida em que ponderamos todas estas questòes. Como as premissas da psicologia junguiana foram construídas a partir das fantásticas descobertas da mente privilegiada de Jung ao se confrontar com a força arquetípica, parece-nos que nossas novas elaboraçòes precisam também ser feitas "de dentro para fora" e não meramente a partir de premissas lógicas conscientes - até porque toda nova construção aqui deve ser interativa e processual, já que a psicologia junguiana em nenhum momento se descuida das relações das partes com o todo. É desta interação que obteremos as respostas para problemas que ainda nào estào completamente claros, como o de um possível "inconsciente cultural." Parafraseando Jung, a nossa crítica deveria também ser a de "um inconsciente que se realizou."

23. Henderson, passim. 


\section{Referências bibliográficas}

Adams, Michael Vannoy. The multicultural imagination. London: Routledge, 1996.

Adorno, Theodor e Max Horkheimer, Dialectic of enlightenment. (New York: Continuum, 1993.)

Arnold, Matthew. Culture and anarchy. New York: MacMillan, 1925.

Benedict, Barbara M. Making the modern reader: cultural mediation in early modern literary anthologies. (Princeton, NJ: Princeton U. Press, 1996.)

Bernheimer, Charles, ed. Comparative literature in the age of multiculturalism. (Baltimore: Johns Hopkins U. Press, 1995) .

Bloom, Harold. The western canon: the books and schools of the ages. New York: HartcourtBrace, 1994.

During, Simon. The cultural studies reader: London: Routledge, 1999.

Fanon, Frantz. Black skin, white masks. tr. Charles Markmann. New York: Grove Press, 1991.

Harris, Marvin. Cultural anthropology. s.l. : Addison-Wesley, 1995.

Henderson, Joseph L. Shadow and self: selected papers in analytical Psychology. Wilmette, Il.: Chiron, 1990.

Hinz, Evelyn J. and John J. Teunissen. Cultura e bumanidades: a abordagem arquetípica. Leitura: Revista do Programa de Pós-Graduaçào em Letras da UFAL. Número Especial: Crítica Junguiana, org. Cláudia Canuto. Jan 1995-Dez 1996.

Hirsch Jr., E. D. Cultural literacy: what every american needs to know. Boston: HoughtonMifflin, 1987. 
Inglis, Fred. Cultural studies. London: Blackwell, 1994.

Jung, C. G. Aspectos do drama contemporâneo. Petrópolis, Vozes, 1990.

Levin, Harry. "New Frontiers in the Humanities," Contexts of Criticism, Harvard Studies in Comparative Literature 22 (Cambridge: Harvard U. Press, 1957) .

Patey, Douglas Lane. "The Eighteenth Century Invents the Canon." Modern Language Studies 18, no. 1 (Winter 1988)

Robell, Suzanne. "Jung e Cultura." Rubedo. Online. 12 Out. 1999.

Shweder, Richard A., Thinking through cultures: expeditions in cultural psychology. Cambridge, Ma: Harvard U. Press, 1991. 